\title{
The Woody Vegetation of Eastern Senegal
}

\author{
ALEX DICKIE, IV; REX D. PIEPER; AND JAMES R. DICKEY
}

\begin{abstract}
The woody component of the vegetation of eastern Senegal was sampled using the point-centered quarter method. Data were evaluated using cluster, principal component, and multiple discriminant analysis (MDA) techniques. Sítes were grouped into 8 ecologically significant groups. Six of these groups were considered woodland lateritic sites, and 2 drainage sediment sites. Species of the genus Combretum dominated all sites. The effect of livestock grazing on the botanical composition was inferred through the use of 4 environmental variables as discriminant factors in MDA. A floristic record of species composition and guidelines for management are embodied in the results of the analyses.
\end{abstract}

\section{Key Words: Sahel, Combretum, vegetational analysis}

Many ecologists are concerned that livestock water developments in the Sahel have negative consequences because they allow numbers of animals to increase (Sandford 1983). Without control of grazing, livestock water developments may simply allow additional areas to be degraded. In the Sahel such exploitation is critical because of the fragile nature of the ecosystem involved. ${ }^{1}$ Much of the rural population in this area depend directly on livestock for survival. Problems of survival in the Sahel are intensified by reoccurring severe drought. The 1968-74 drought resulted in high mortality of livestock and starvation among the human population.

\footnotetext{
Authors are former graduate student and professor, Animal and Range Sciences Department, New Mexico State Univ., Las Cruces, and livestock economist, Winrock Int 1., Dahka, Bangledesh. Alex Dickie served as range management advisor for Aid for International Development in Senegal during 1979-1981. He is now a graduate research assistant in the Department of Range Science, Utah State University, Logan. Data for this paper were collected through the United States Agency for International Development, Eastern Senegal Range Livestock Development Project No. 685-0202.

Manuscript accepted 10 July 1986.
}

IThomas, G.W. 1980. The Sahelian/Sudanian zones of Africa. Profile of a fragile environment. Report to the Rockefeller Foundation. New Mex. State Univ., Las Cruces.
The objective of this study was to describe and classify the woody vegetation in an area in eastern Senegal. Baseline data were needed to measure changes resulting from livestock water point developments and periodic drought. Emphasis was confined to the relatively stable woody component of the vegetation. Time did not permit an evaluation of the highly variable understory of annual grasses and forbs.

\section{Description of the Study Area}

The study area was a $1,000 \mathrm{~km}^{2}$ area in eastern Senegal, between $14^{\circ}$ and $15^{\circ} \mathrm{N}$ latitude and between $12^{\circ}$ and $13^{\circ} \mathrm{W}$ longitude, about $30 \mathrm{~km}$ southwest of Bakel. Bakel is near the Senegal River, about $500 \mathrm{~km}$ inland from the West African coast (Fig. 1). Twelve Peulh villages are within the area. The villagers are sedentary agro/pastoralists who live in the area yearlong.

The terrain consists of a flat, lateritic plateau dissected by shallow drainage channels and occasionally interrupted by shallow rock depressions. Surface runoff seasonally accumulates in depressions on the lateritic high ground and in catchments in the drainage channels. A few of the natural catchments store water for several months after the rains and provide an important source of water for livestock and wild animals. Perennial water is only available in association with villages where hand dug wells are constructed.

Rainfall generally falls during a 60-day period between 1 June and 30 September. Average yearly rainfall for 1975 through 1980 was $450 \mathrm{~mm}$. Information concerning the vegetation of Senegal is very general and some applies more directly to less forested areas (Naegele 1971, ORSTOM 1975). Vegetation of the study area consisted of a savanna with a herbaceous understory of annual grasses.

\section{Methods}

To insure complete coverage during the time available, subdivision of plant community types was made only to the level of the 2 major soil types, i.e., the lateritic and drainage sediment soils. Sample sites were selected using the "subjective-without-preconceived- 


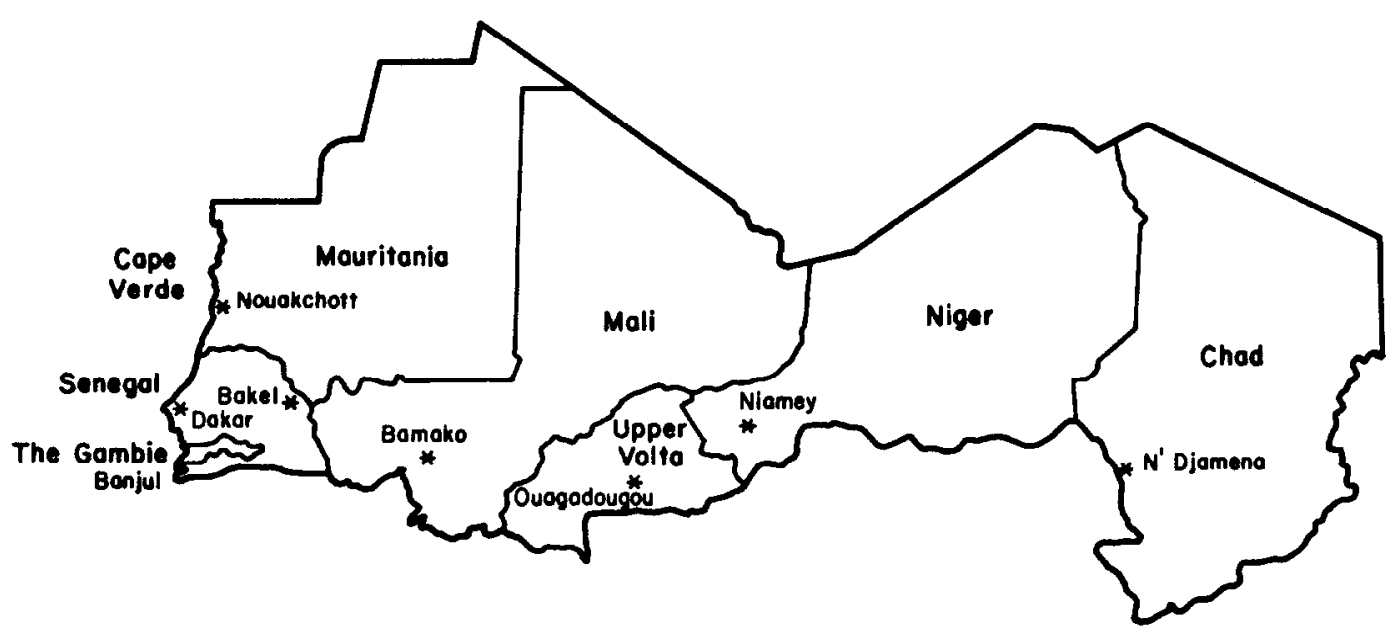

Fig. 1. Map of the Sahel region of western Africa showing study location.

bias" approach (Mueller-Dombois and Ellenberg 1974). With this approach the investigator is expected to discriminate wherever common sense and experience make a distinction obligatory. Within the 2 edaphically defined entities, sample units were located subjectively on the basis of perceived livestock utilization patterns.

The point-centered quarter method was used to obtain detailed information about the population of woody plants (Dix 1961). In addition to point-centered quarter sampling, a releve tally sheet (Mueller-Dombois and Ellenberg 1974) was completed for each sample unit. The cover/abundance scale of Braun-Blanquet (1932) was used to assign values to each species.

Relative density, relative frequency, relative dominance, and importance values were calculated. Importance values were calculated as the sum of relative density, relative frequency, and relative dominance (Mueller-Dombois and Ellenberg 1974). Importance values were summed and averaged for each species over all sample units. Those species with importance values $\geq 2.0$ were separated from the total species group. Analysis of vegetation data was limited to the more prevalent species.

Point-centered quarter data as summarized above were subjected to cluster analysis. The polythetic, agglomerative, hierarchical procedures that were employed followed the general theory of clustering strategies presented by Lance and Williams (1967) and Orloci (1978). The procedure is based on a distance measure comparing all possible pairs of sample units. Average standard euclidean distance grouped sample units in a way that described the ecological relationships in the field as they were understood by the investigators. The average standard euclidean option calculates the distance between 2 points in euclidean space and tends to emphasize the larger differences in abundance of the species not in common between 2 sample units being compared.

The selected clustering strategy, or actual method of grouping sample units, was the flexible strategy. Briefly, a matrix D was constructed showing all possible pair combinations of sample

Table 1. Multiple discriminant analysis, cluster group member sample units, and mean values of environmental variables.

\begin{tabular}{|c|c|c|c|c|c|c|c|c|c|}
\hline \multirow{4}{*}{ Group } & \multirow{4}{*}{ S.U. Members } & \multicolumn{8}{|c|}{ Environmental variable $\bar{X}$} \\
\hline & & \multicolumn{8}{|c|}{ Distance } \\
\hline & & \multicolumn{2}{|c|}{ Permanent $\mathrm{H}_{2} \mathrm{O}$} & \multicolumn{2}{|c|}{ Temporary $\mathrm{H}_{2} \mathrm{O}$} & \multicolumn{2}{|c|}{ N/Baseline } & \multirow{2}{*}{\multicolumn{2}{|c|}{$\begin{array}{c}\text { Soil Code' } \\
\text { SE } \\
\end{array}$}} \\
\hline & & $\mathbf{K m}$ & $\mathrm{SE}^{2}$ & $\mathrm{Km}$ & SE & $\mathbf{K} \mathbf{m}$ & SE & & \\
\hline I & $\begin{array}{l}76,83,6,15,28,60 \\
79,31,59,40,61,49 \\
73,77,1,53,43,34 \\
45,38,17,70,72,44\end{array}$ & $\overline{6}$ & 2.8 & 1.4 & 1.8 & 19.4 & 7 & 1.1 & .4 \\
\hline II & $\begin{array}{l}5,42,39,20,16,23 \\
11,38\end{array}$ & 3.4 & 1.6 & 2.8 & 2.1 & 14.4 & 7.9 & 1.0 & 0 \\
\hline 111 & $\begin{array}{l}2,46,54,3,30,65 \\
52,55\end{array}$ & 4 & 1.5 & 1.9 & 1.5 & 25.3 & 4.7 & 1.5 & .8 \\
\hline IV & $\begin{array}{l}10,51,19,58,36,41 \\
47\end{array}$ & 7.7 & 3.7 & 3.3 & 1.7 & 15.3 & 10.1 & 2 & $\mathbf{0}$ \\
\hline $\mathbf{v}$ & $\begin{array}{l}4,14,25,37,50,27 \\
29,63,74\end{array}$ & 3.7 & 3.7 & 3.2 & 2.1 & 15.2 & 8.1 & 1.4 & .7 \\
\hline VI & $\begin{array}{l}18,62,33,78,80,79 \\
82,81\end{array}$ & 3.7 & 2.5 & 3.4 & .9 & 13.3 & 5.7 & 2.0 & 0 \\
\hline VII & $8,32,35,75,26,64$ & 4.5 & 3.5 & 3.3 & 1.5 & 18.3 & 5.6 & 2.2 & .4 \\
\hline VIII & $56,66,67,68,69$ & 1.4 & 1.5 & .7 & .6 & 15.6 & 7.9 & 1.4 & .6 \\
\hline
\end{tabular}

'Soil Code 1 = Laterite

2 = Drainage Sediment

$3=$ Other

2SE = Standard error 
Table 2. Mean importance value of species with constancy value $>55 \%$ for eight groups differentiated by chaster analyais. Groups I, III, II, V, VII, and VIII are representative of the woodland laterite site. Groups IV and VI represent the drainage sediment woodland site.

\begin{tabular}{|c|c|c|c|c|c|c|c|c|c|c|c|c|c|c|c|c|}
\hline \multirow[b]{3}{*}{ Species } & & \multicolumn{15}{|c|}{ Woodland } \\
\hline & \multicolumn{3}{|c|}{$\begin{array}{c}\text { Combretum } \\
\text { gl. } \\
\text { Grewia } \\
\text { bi. }\end{array}$} & \multicolumn{2}{|c|}{$\begin{array}{c}\text { Sterculia } \\
\text { se. } \\
\text { Combretum } \\
\text { gl. } \\
\end{array}$} & \multicolumn{2}{|c|}{$\begin{array}{c}\text {-Combretum } \\
\text { ni. }\end{array}$} & \multicolumn{2}{|c|}{$\begin{array}{c}\text { Combretum } \\
\text { lg. } \\
\text { Combretum } \\
\text { mi. } \\
\text { Guiera } \\
\text { se. } \\
\end{array}$} & \multicolumn{2}{|c|}{$\begin{array}{c}\text {-Combretum } \\
\text { ni. } \\
\text {-Grewia } \\
\text { bi. }\end{array}$} & \multicolumn{2}{|c|}{$\begin{array}{c}\text { Anogeissus le. } \\
\text { Combretum - } \\
\text { gl. } \\
\text { Combretum } \\
\text { ml. }\end{array}$} & \multicolumn{2}{|c|}{$\begin{array}{l}\text { Combretum } \\
\text { ge. }\end{array}$} & \multirow[b]{2}{*}{$\% \mathrm{C}$} \\
\hline & $\bar{X} \mathbf{I}$. V. & $\% \mathrm{C}$ & $\bar{X} 1 . V$. & $\% \mathrm{C}$ & $\bar{X} 1 . V$. & . $\% \mathrm{C}$ & $\bar{X} I . V$. & $\% \mathrm{C}$ & $\bar{X} I . V$. & $\% \mathrm{C}$ & $\bar{X} \mathbf{I} . \mathbf{V}$. & $\% \mathrm{C}$ & $\bar{X} I . V$. & $\% \mathrm{C}$ & $\bar{X} \mathbf{I} . V$. & \\
\hline Sterculia setigera (Stse) $\mathrm{T}^{\imath}$ & & & & & 70 & 88 & & & & & & & & & & \\
\hline Grewia tenax (Grte) S & & & & & & & & & & & 33 & 80 & & & & \\
\hline Ziziphus mucronata (Zimu) S & & & & & & & & & & & 18 & 60 & & & & \\
\hline Acacia ataxacantha (Acat) $\mathrm{S}$ & & & 10 & 100 & & & & & & & 22 & 60 & & & & \\
\hline Combretum nigricans (Coni) $\mathrm{T}$ & 84 & 88 & 52 & 88 & 79 & 100 & 42 & 100 & 90 & 83 & & & 39 & 100 & & \\
\hline Grewia bicolor (Grbi) S & 45 & 100 & 88 & 100 & 37 & 88 & 29 & 89 & 42 & 100 & 39 & 100 & 44 & 86 & & \\
\hline Pterocarpus lucens (Ptlu) T & & & 21 & 100 & & & 37 & 89 & 57 & 67 & 27 & 100 & & & & \\
\hline Bombax costatum (Boco) $\mathrm{T}$ & 25 & 68 & & & 23 & 88 & 18 & 67 & 43 & 83 & & & 23 & 100 & & \\
\hline Cassia sieberiana (Casi) T & 19 & 60 & 11 & 63 & 8 & 88 & 18 & 67 & & & & & 19 & 86 & & \\
\hline Boscia senegalensis (Bose) S & 13 & 56 & 15 & 88 & & & & & & & 41 & 60 & 14 & 78 & & \\
\hline Pterocarpus erinaceus (Pter) T & & & & & 12 & 63 & & & & & & & & & 21 & 75 \\
\hline Combretum glutinosum (Cogl) T & 157 & 100 & 103 & 100 & 124 & 100 & 128 & 100 & 60 & 100 & 53 & 100 & 73 & 100 & 95 & 100 \\
\hline Combretum micranthum (Comi) $\mathrm{S}$ & 18 & 88 & 38 & 100 & 21 & 88 & 23 & 100 & 37 & 67 & 119 & 100 & 57 & 100 & 18 & 88 \\
\hline Guiera senegalensis (Guse) $\mathrm{S}$ & 25 & 92 & 52 & 100 & 37 & 75 & 98 & 100 & 88 & 100 & 93 & 100 & 34 & 100 & 48 & 100 \\
\hline Combretum geitonophyllum (Coge) $\mathrm{T}$ & 23 & 80 & 10 & 61 & 13 & 63 & & & & & 20 & 60 & 22 & 71 & 55 & 100 \\
\hline Acacia macrostachya(Acma) S & 47 & 76 & 44 & 100 & & & & & 22 & 83 & & & 62 & 100 & 37 & 88 \\
\hline Feretia apodanthera (Fcap) $\mathrm{T}$ & 8 & 56 & & & 10 & 75 & & & 13 & 67 & 8 & 80 & 15 & 86 & 15 & 100 \\
\hline Acacia seyal (Acse) $\mathrm{T}$ & & & & & & & & & & & 18 & 60 & 17 & 86 & 20 & 88 \\
\hline Anogeissus leiocarpum (Anle) $\mathrm{T}$ & & & & & & & & & & & & & 45 & 86 & 23 & 88 \\
\hline Dichrostachys cinerea (Dici) $\mathbf{T}$ & & & & & & & & & & & & & & & 18 & 75 \\
\hline Entada africana (Enaf) $T$ & & & & & & & & & & & & & 10 & 86 & & \\
\hline Combretum aculeatum (Coac) T & & & & & & & & & & & & & & & 10 & $\begin{array}{l}63 \\
63\end{array}$ \\
\hline Ostryoderris stuhlmanni (Osst) $\mathrm{T}$ & & & & & & & & & & & & & & & 14 & 63 \\
\hline Piliostigma reticulatum (Pire) T & & & & & & & & & & & & & & & 22 & 88 \\
\hline Sclerocarya birrea (Scbi) T & & & & & & & & & & & & & & & 17 & 88 \\
\hline Strychnos spinosus (Stsp) T & & & & & & & & & & & & & 11 & 71 & & \\
\hline Terminalia macroptera (Tema) T & & & & & & & & & & & & & & & 38 & 81 \\
\hline
\end{tabular}

$1 \mathrm{~T}$ indicates a tree; $\mathrm{S}$ a shrub.

units. The matrix was reduced by calculating the distance of newly formed groups of joined sample units with all other sample units. The following linear model was used:

$D_{j \mathbf{k}}, 1=$ Alpha $\mathbf{j} \times d_{j \mathbf{l}}+$ Alpha $\mathbf{k} \times \mathbf{d}_{\mathbf{k} \mathbf{l}}+$ Beta $S \mathbf{d}_{\mathbf{j}}$ where the distance between a group formed from sample units and/or groups $j$ and $k$, and a third sample unit and/or group can be calculated from the known distances $d_{j k}, d_{j l}$, and $d_{k l}$ and the parameters Alpha and Beta. Beta is flexible with the constraint that Alpha j + Alpha k + Beta $=1$, and that Alpha $\mathrm{j}=$ Alpha $\mathrm{k}$. Beta $=-.25$ has been found appropriate for most purposes, and was used in this analysis. The values Alpha $j=.625$, Alpha $k=.625$, and Beta $=-.25$ were used. With the parameters $=1$, then successive hierarchial joinings are monotonic and reversals do not occur ${ }^{2}$.

Principal component analysis (PCA) was used to arrange sample units and species in a coordinate system such that species distances are an accurate reflection of their ecological similarity. The method used follows the scheme and terminology of Orloci (1966, 1967).

Multiple discriminant analysis (MDA) was used in a multivariate community comparison test. The procedure employed follows the method first used by Fisher (1936) and Mahalanobis (1936) and described recently by Lindeman et al. (1980). Groups identified from the cluster analysis and verified by the principal component analysis were compared in a pair-wise fashion with a $\mathrm{D}^{2}$ statistic calculated as a measure of the multivariate distance between pairs of communities. An $F$ ratio associated with the $D^{2}$ statistic was used to test the statistical significance of each $D^{2}$ distance. Four environmental variables were evaluated by the MDA program.

2Ludwig, J.L. 1982. Community classification-polythetic, agglomerative, hierachial. Biol. Dept. New Mex. State Univ., Las Cruces, NM.
For each sample unit, values were entered for (1) distance to the nearest village with permanent water supply, (2) distance to the nearest natural seasonal water hole, (3) distance north of a baseline drawn on the horizontal axis at the southernmost point of the project area, and (4) soil type. Distances were measured in a straight line on a 1:50,000 scale map. Soil type was simplified to the 3 types, laterite, drainage sediment, and other.

\section{Results}

\section{Vegetation Inventory}

A total of 70 woody species were identified on the sample units (S.U.) in the analysis. Of the 70 species, 52 were identified by their scientific names. The remaining species were extremely rare in the study area. Twenty-nine of the species had mean importance values (I.V.) $>2.0$.

\section{Vegetation Classification}

Cluster analysis differentiated 8 groups considered ecologically significant (Table 1). The groups were designated for the dominant woody species which occurred there.

Principal component analysis produced component scores for the ordination of sample units and species in coordinate systems. Figure 2 shows all 79 S.U.s arranged in 2-dimensional space, such that intersample unit distances are an accurate reflection of their ecological resemblance. S.U. ordination groups are labeled by Roman numerals to show agreement with cluster analysis groups. S.U.s of group VIII were widely dispersed by PCA analysis. No attempt was made to force the S.U.s to group in euclidean space. Otherwise, outlying S.U.'s affiliations for various PCA groups (as suggested by cluster analysis) are shown by directional arrows. 


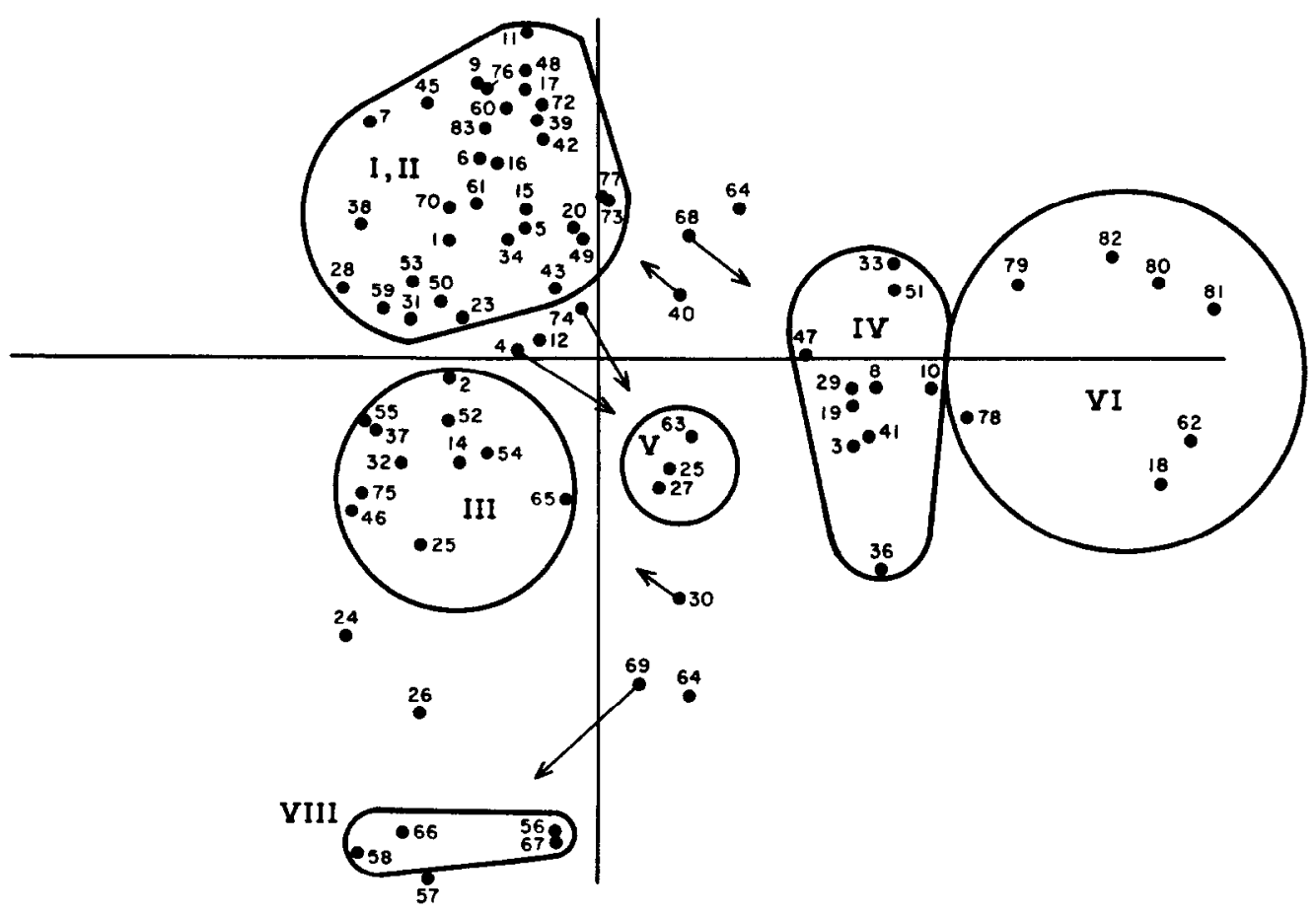

Fig. 2. Principal component analysis and sample unit ordination.

Table 2 lists the sample unit members for each of the 8 cluster groups as they were used in multiple discriminant analysis. S.U.'s 71, 57, and 24 were eliminated before subjecting the data to MDA. It was decided, subjectively, that their presence would confound interpretation, as they are not representative of a group and would detract from intra-group homogeneity.

Intra-group similarities of sample units and distinctions indicated by inter-group comparisons led to the construction of Table 2. Constancy values (percentage of sample units in which the species occurred) were calculated within each group. The table lists the mean importance values of species with constancy values $>55 \%$ for the $\mathbf{8}$ groups differentiated by cluster analysis. The table is designed to facilitate intra- and inter-group comparison of species importance values and percent constancy.

As shown in Table 3, groups I, II, III, V, VII and VIII are similar. Five of these 6 groups are variants of the community type that is common for the lateritic site in the study area. For the sake of this discussion, group I will be considered the core representative of the lateritic community. The unique characteristics of groups II, III, V, VII, and VIII are highlighted by comparing them to group I.

Groups IV and VI are representative of the more productive drainage sediment site. The $\mathbf{2}$ groups are presented as a separate community type following the discussion pertaining to the lateritic site.

\section{Combretum Laterite Woodland}

The 24 sample units of group I represent the identification, distance and basal area measurements of 2,500 trees. All sample units of the group but 1 occurred on a lateritic soil (Table 1). The mean distance to the nearest village with permanent water was 6 $\mathrm{km}$ while the mean distance to temporary water was $1.4 \mathrm{~km}$. Variable 3, mean distance north of the southern baseline was 19.4 $\mathrm{km}$, where $35 \mathrm{~km}$ is the maximum possible. Group I therefore appears representative of the area outside zones of constant use around permanent settlements. Proximity to temporary water holes indicates concentrated seasonal use during the rainy season and in the early-to-mid dry season. The sample units that form group I occur in the more xeric, northern half of the study area.

The species composition and values given for mean importance and percent constancy in group I of Table 2 are typical of the vegetation community found on the dry lateritic soils subjected to moderate use. Four species of the genus Combretum have constancy values $\geq 80 \%$. Combretum glutinosum, the dominant overstory species, had a mean importance value of 157 and was $100 \%$

Table 3. Multiple discriminant analysis: calculated statistical values for group pairs.

\begin{tabular}{|c|c|c|c|c|c|c|c|}
\hline & \multicolumn{7}{|c|}{ Group 1 to Groups } \\
\hline & II & III & IV & V & VI & VII & VIII \\
\hline Sign. by $\underset{\mathbf{R}^{2}}{\mathrm{D}^{2}}$ & $\begin{array}{l}1.67 \\
2.28 \\
0.25\end{array}$ & $\begin{array}{l}2.41 \\
3.29 \\
0.32\end{array}$ & $\begin{array}{l}7.42 \\
9.13 * 2 \\
0.58\end{array}$ & $\begin{array}{l}2.38 \\
3.57^{*} \\
0.33\end{array}$ & $\begin{array}{c}9.57 \\
13.10^{* *} \\
0.65\end{array}$ & $\begin{array}{l}6.98 \\
7.56 * * \\
0.54\end{array}$ & $\begin{array}{l}4.02 \\
3.73^{\star} \\
0.37\end{array}$ \\
\hline \multicolumn{8}{|l|}{$\begin{array}{l}\text { Disc. Fun. F. values for } \\
\text { Environmental variable }\end{array}$} \\
\hline $\begin{array}{l}\text { 1. Dist. to perm } \mathrm{H}_{2} \mathrm{O} \\
\text { 2. Dist. to temp } \mathrm{H}_{2} \mathrm{O} \\
\text { 3. Dist. north of Base line } \\
\text { 4. Soil type }\end{array}$ & $\begin{array}{c}17.39 * * \\
5.50^{*} \\
4.14 \\
0.20\end{array}$ & $\begin{array}{c}25.51^{* *} \\
0.0 \\
23.34^{* *} \\
6.86^{*}\end{array}$ & $\begin{array}{l}0.72 \\
8.41 * * \\
2.32 \\
76.67 * *\end{array}$ & $\begin{array}{l}5.69^{*} \\
30.83^{*} \\
1.78 \\
9.08^{* *}\end{array}$ & $\begin{array}{l}1.69 \\
8.40^{* *} \\
3.69^{*} \\
61.99^{* *}\end{array}$ & $\begin{array}{c}0.42 \\
3.73 \\
0.03 \\
108.96^{* *}\end{array}$ & $\begin{array}{c}74.81^{*} \\
2.74 \\
0.0 \\
2.83\end{array}$ \\
\hline
\end{tabular}


constant among sample units of the group.

These data suggest that the genus Combretum has a strong influence on the group I vegetation type, thus group I may be generally referred to as a Combretum woodland community. Acacia macrostachy, Combretum micranthum, Grewia bicolor and Guiera senegalensis typified the understory shrub layer. The community typified by group I is representative of about $60 \%$ of the vegetation in the study area.

Group II contained 8 sample units (Table 1). All sample units occurred on the lateritic soil type. The mean distance to permanent water was $3.4 \mathrm{~km}$; the mean distance to temporary water was 2.8 $\mathrm{km}$, and the mean distance north placed the sample unit group in the mid-to-southern portion of the study area. There were 11 species in both group II and group I; mean importance value and percent constancy were almost identical for Combretum geitonophyllum, $C$. glutinosum, $C$. micranthum, and $C$. nigricans. The difference between the groups is that Acacia macrostachya and Boscia senegalensis of group I are replaced by Pterocarpus erinaceus and Sterculia setigera in group II. Acacia macrostachya and Boscia senegalensis are shrubby species that do well under dry conditions. Both Petercarpus erinaceus and Sterculia setigera are large $(>10 \mathrm{~m})$ trees. Although Sterculia trees occurred throughout the study area, their greatest concentrations were in the more moist, southern portion. Group II is representative of the Sterculia-Combretum woodland type that covered most of the mid-to-southern portion of the study area. As a variant of the group I Combretum woodland lateritic community, group II covered approximately $40 \%$ of the estimated $60 \%$ for group I.

In the typical Sterculia-Combretum woodland community, Sterculia trees stand 4 to $8 \mathrm{~m}$ above the canopy layer formed by Combretum spp. The understory shrub layer, as in group I, was typified by Combretum micranthum, Grewia bicolor and Guiera senegalensis.

An ecological association between Sterculia setigera and Adansonia digitata was noted in the field and is indicated by the species ordination (Fig. 3) (species abbreviations are shown in Table 2). The 2 species are circled and labeled $B$ for reader identification. Adansonia digitata, more commonly known as "Baobab," had a $50 \%$ constancy value among the sample units of group II.

Mahalanobis $\mathrm{D}^{2}$ value for the group I-group II comparison was nonsignificant ( $\alpha \leq .05$ ) (Table 3). A low, nonsignificant value was expected since group II is a relatively simple variant of the group I type. The discriminant function $F$ value for the mean distance to

- Cogl

- Coni

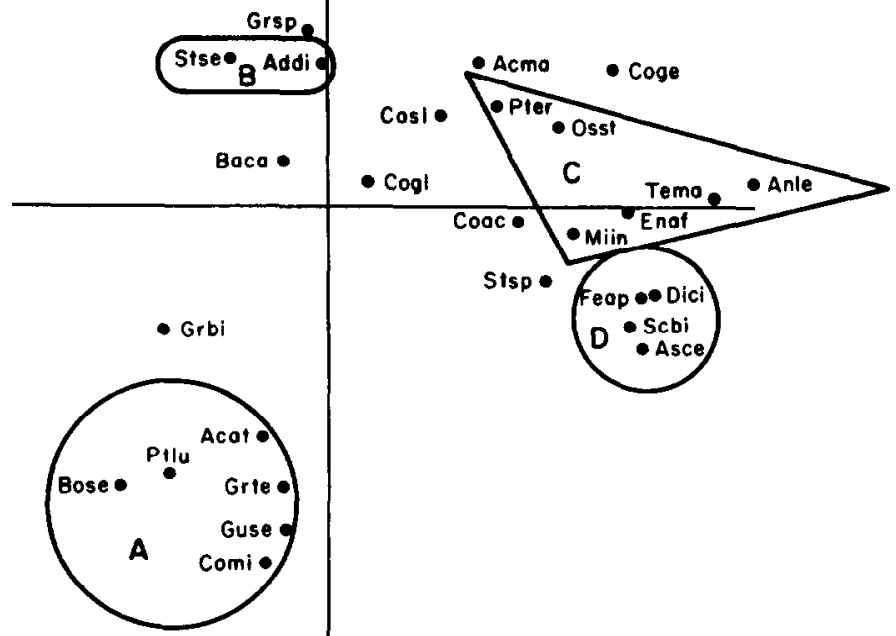

Fig. 3. Principal component analysis and species ordination. permanent water was significant $(\alpha \leq 01)$ (Table 3$)$. The highly significant value resulted from the fact that the sample unit members of group I were in the northern-to-mid latitudes and were relatively far from permanent settlements. Group II sample units were in the southern half of the study area where people and permanent water supplies are more concentrated.

The sample unit members of group III were at moderate distances from permanent and temporary water in the northern third of the study area (Table 1). Group III, like group I, had an overstory layer dominated by Combretum spp. (Table 2). As a variant of the group I type, it is interesting because it includes sample units $3, \mathbf{3 0}$, and 65 (Table 1). These 3 sample units are on drainage sediment soils in areas that are heavily utilized by livestock. Importance values for the dominant shrub species Combretum micranthum, Grewia bicolor, and Guiera senegalensis were higher in group III than in group $I$. The importance values of the 2 dominant overstory species, Combretum glutinosum and Combretum geitonaphyllum, are comparatively low. This kind of change in community structure is to be expected on the lateritic site, where moisture conditions are more favorable with light-to-moderate use, or on the drainage sediment site where heavy use creates more xeric conditions. Intergroup comparison with group I revealed a significant $D^{2}$ value $(\alpha \leq .05)$ (Table 3$)$.

The sample unit members of group V were not close to permanent or temporary water; they had a mean distance of $15.2 \mathrm{~km}$ north of the baseline and were on either the laterite or drainage sediment sites (Table 1). The 2 sample units (27 and 74) of the group that were on drainage sediment soils were in heavily utilized areas. Species composition of these 2 sample units had been modified through heavy use. The importance value of understory shrubs was higher, and the importance values of the $\mathbf{2}$ dominant overstory species were reduced compared to those of group I. The $D^{2}$ value calculated for the group I to group V comparison was significant $(\alpha \leq .05)$. Discriminant function coefficient $F$ values were significant for the first, second, and fourth environmental variables (Table 3).

The sample units in group VII were grouped due to their dissimilarity with characteristics of the other drainage woodland groups. Group VII consisted of a mixture of sample units that represented a seral community type. All the sample units appeared to be highly disturbed. The group is probably representative of the drainage woodland community under stress. Heavy utilization pressure has altered species composition so that the drainage woodland community resembled the more xeric lateritic group I type. In comparison with the S.U.s of the woodland type (groups IV and VI), S.U.s in group VII have less diversity (Table 3 ), lower tree densities, and a smaller average tree diameters (Table 4).

Table 4. Group average values for number of trees per 100 square meters, total basal area per 100 trees and individual tree diameters.

\begin{tabular}{lcccccc}
\hline & \multicolumn{5}{c}{ Average Values Per Group } \\
\cline { 2 - 7 } & $\begin{array}{c}\text { Trees } \\
\text { per 100 }\end{array}$ & $\begin{array}{c}\text { Standard } \\
\text { Group }\end{array}$ & $\begin{array}{c}\text { Total } \\
\text { Basal Area/ } \\
\text { 100 Trees }\end{array}$ & $\begin{array}{c}\text { Standard } \\
\text { Error }\end{array}$ & $\begin{array}{c}\text { Miameter } \\
\text { (cm) }\end{array}$ & $\begin{array}{c}\text { Standard } \\
\text { Error }\end{array}$ \\
\hline I & 2.8 & 0.9 & 28505 & 15607 & 17 & 12.5 \\
II & 2.6 & 0.7 & 45664 & 21872 & 21 & 14.8 \\
III & 4.2 & 2.5 & 23642 & 6430 & 15 & 8.0 \\
IV & 2.9 & 0.9 & 40390 & 20791 & 20 & 14.4 \\
V & 3.6 & 1.6 & 25490 & 12840 & 16 & 11.3 \\
VI & 3.8 & 1.1 & 48436 & 24132 & 22 & 15.5 \\
VII & 2.8 & 1.8 & 34082 & 17139 & 19 & 13.0 \\
VIII & 3.3 & 1.4 & 28030 & 17272 & 17 & 13.0 \\
\hline
\end{tabular}

The $\mathrm{D}^{2}$ values for the group I-group VII comparison was significant $(\alpha \leq .01)$ (Table 3$)$.

The sample unit members of group VIII were all close to permanent and temporary water and were on the laterite or drainage sediment soils (Table 1). The mean distance to permanent water for 
group VIII was only $1.4 \mathrm{~km}$. Table 2 shows that species composition is altered from the group I, typical community, in favor of shrubby species. All of the species typified by group VIII are highly resistant to grazing pressure. Acacia ataxacantha and Ziziphus mucronata are thorny shrubs that resist grazing pressure even by goats.

Acacia ataxacantha is in the species association of Figure 3 that is marked $A$ for reader identification. The species of this association appear to be persistent under grazing pressure. They all have a wide range ecological adaptability and were found on both laterite and drainage sediment sites. Ziziphus mucronata had a low overall importance value of $<2.0$ and was therefore not among the 29 species used in the computer-assisted analysis.

For the group I-VIII comparison, the $\mathrm{D}^{2}$ value was significant $(\alpha \leq .05)$. The discriminant function coefficient $F$ value calculated for the distance to permanent water was significant $(\alpha \leq .01)$ for the pair (Table 3). The sample unit associations of groups VII and VIII suggest that the plant communities around permanent settlements and in areas of heavy grazing were severely disturbed.

\section{Anogeissus-Combretum Drainage Woodland}

Groups IV and VI represented sample units at moderate-togreat distances from permanent water and were relatively far from temporary water. The mean distance of these groups was $14 \mathrm{~km}$ above the baseline and all were on drainage sediment soil (Table 1). The species composition and values given for mean importance and percent constancy for these 2 groups (Table 2) were typical of the vegetation community found on the more productive drainage sediment site under moderate use. The large trees Anogeissus leiocarpum, Combretum glutinosum and Acacia seyal dominated and typified the drainage sediment site. Also typical, though less abundant, were the trees Entada africana, Pterocarpus erinaceus, Ostryoderris stuhlmanni and Sclerocarya bierrea. Understory vegetation was dominated by Combretum spp., Grewia spp., and others.

The triangle marked $\mathrm{C}$ in the species ordination of Figure 3 includes most of the large trees which dominated the drainage sediment site. The encircled species marked D occurred in association with one another in the deeper drainage channels of the mid-to-southern portion of the study area. Sclerocarya birrea and Acacia seyal occurred only on the more productive soils. Acacia seyal was most often found at the edge of drainage channels, whereas Sclerocarya birrea tended to occur near the center of a drainage, where its base may be intermittently submerged in water for short periods of time. Acacia seyal may be shade intolerant and have a tap root which can reach the water it needs. Feretia apodanthera appeared to be a species with wide latitude of adaptability. It was common on both laterite and drainage sediment soils.

When they were paired with group I, groups IV and VI produced significant $D^{2}$ values $(\alpha \leq .01)$. Values for the coefficient of determination $\left(R^{2}\right)$ were high for both pairs (Table 3 ).

\section{Interpretations for Management}

The results of these analyses indicate that significant changes in botanical composition occurred in the study area before new seasonal water points were introduced. The groupings of woody species in the preceding section suggest that the community composition of woody species surrounding a water point can be significant- ly affected by distance to the nearest village. This may be inferred from the results of multiple discriminant analysis where the first discriminating variable was distance to permanent water (a village). Specific botanical changes associated with overuse are illustrated in the group comparisons. For example, overuse of an area by livestock can shift botanical composition to reflect more xeric conditions. As stated, group VII's botanical composition (Table 2) indicates similarity to the drier lateritic community type, while the sample units of group VII were all on soils of the drainage woodland community type. When perennial overstory cover is diminished, soil degradation through heating, compaction and erosion follows. Loss of preferred forage species such as Combretum aculeatum and Maerua angolensis will quickly result in lower livestock productivity. When dominant overstory species such as Ostryoderris stuhlmanni and Cassia sieberiana disappear from the community (Table 3) a trend toward degradation may be indicated. Since woody species provide most of the perennial cover, and therefore the only long-term site protection, it is difficult to imagine that removal of any woody species can be justified for the sake of "increased livestock production". We suggest that care should be taken to avoid the loss of species diversity. Although "proper" stocking rates are not known, it would be prudent to reduce grazing pressure on drainage woodland community sites. Moderate grazing is especially important in proximity to permanent water where livestock must concentrate in the dry season. Protection and rational use of woody species should be encouraged. Management and future research should look for ways to insure regeneration of preferred perennial vegetation (in this case, trees and shrubs) and site stability.

\section{Literature Cited}

Braun-Blanquet, J. 1932. Plant sociology. McGraw-Hill Book Co., New York.

Dix, R.L. 1961. An application of the point-centered quarter method to the sampling of grassland vegetation. J. Range Manage. 14:63-69.

Fisher, R.A. 1936. The use of multiple measurement in taxonomic problems. Ann. Human Gen. 7:197-198.

Lance, G.N., and W.T. Williams. 1967. A general theory for classificatory sorting strategies. I. Hierarchial Systems. Computer J. 9:373-380.

Lindeman, R.H., P.F. Merendo, and R.L. Gold. 1980. Introduction to bivariate and multivariate analysis. Scott, Foresman, and Company. Glenview, Ill.

Mahalanobis, P.C. 1936. On the generalized distance in statistics. Proc. Nat. Inst. Sci. in India. 12:49-55.

Mueller-Dombois, D., and H. Ellenbers. 1974. Aims and methods of vegetation ecology. John Wiley and Sons. New York.

Naegele, A.F.G. 1971. Etude et Amelioration de la Zone Pastorale du Nord-Senegal. Food and Agriculture Organization of the United Nations. Rome.

Orloci, L. 1966. Geometric models in ecology. The theory and application of some ordination techniques. J. Ecol. 54:193-215.

Orloci, L. 1967. Data centering: a review and evaluation with preference to component analysis. Syst. Zoology. 16:208-212.

Orioci, L. 1978. Multivariate analysis in vegetation research. 2 nd ed., Junk. The Hague.

ORSTOM (Organization de Recherche Scientifique et Technique OutreMer). 1975. Carte des pasturager naturals du Ferlo-Boundou (MatamTambacounda-Kidira). Dakar, Senegal.

Sandford, S. 1983. Management of pastoral development in the third world. John Wiley and Sons, New York. 